Appl. Ent. Zool. 4 (3) : 135-146 (1969)

\title{
Ultrastructure and Secretory Mechanism of the Alluring Gland Gell in the Silkworm, Bombyx mori L. (Lepidoptera : Bombycidae)
}

\author{
Yoshio WAKU and Ken-ichi Sumimoto \\ Biology Laboratory, School of Textile Science, \\ Kyoto Technical University, Sakyo-ku, Kyoto, Japan
}

(Received June 2, 1969)

\begin{abstract}
The ultrastructure of the alluring gland cell of the female silkworm, an organ secreting the sex attractant, was examined electron-microscopically with special regard to the mechanism of the production and secretion of the lipoid substance which is the carrier of the pheromone. It is concluded that the lipoid substance is originated from characteristic myelin figures appearing in the pupal cell, while the mitochondria are the starting organelle of such myelin figures. The lipoid substance is then released into the cuticle through the plasma membrane of the microvilli arraying the cell surface, and then finally transported to the outside via pore canals, characteristic to the cuticle of the gland.
\end{abstract}

\section{INTRODUCTION}

The alluring gland of the female silkmoth is probably the most well-known pheromone-producing organ in insects, and this product which attracts the male moth is also popularly known as 'Bombykol' and was first chemically purified as pheromone (Butenand et al., 1959). Cytological investigations of this interesting organ, with special regard to its secretory mechanism, have been carried out since early as the second decade of this century (Iто, 1915, НауAshi and Iто, 1933). Electron microscopic studies of this gland was also performed by STEINBREchT $(1964 \mathrm{~b})$, laying emphasis on the relationship between the sequential change of the alluring activity and the ultrastructural changes of the gland cell. In the present paper our object is to discuss the mechanism of production and release of the secretory substance in and from the gland cell on basis of its fine structure.

\section{MATERIALS AND METHODS}

The silkworm strain 'Shungetsu $\times$ Hosho' was reared with mulberry leaves as usual. The pupal period, in which the alluring gland develops gradually, took about 11 days under a temperature of $25^{\circ} \mathrm{C}$. The gland is a laterally expanded pair of sack-shaped organ, located at the tip of the abdomen. It can be regarded as a specially adapted modification of the usual epidermis for production and secretion of the sex attractant. Thus, the gland cells are covered by ordinary cuticle like the usual epidermal cells other than the gland. Since the gland becomes distinguishable from the neighboring epidermis at the 7th day of pupal development (i.e. 4 days before the emergence of the moth), it was dissected with 
a pair of fine forceps and fixed immediately in ice-cold 5 per cent glutaraldehyde buffered with cacodilate buffer ( $\mathrm{pH} \mathrm{7.4)}$ for $12 \mathrm{hr}$, washed throughly by the same buffer overnight, then post-fixed with 1 per cent osmium tetroxide $(\mathrm{pH} 7.4)$ for $1 \mathrm{hr}$. After dehydration with ethanol series, the tissue was embedded in Epon 812. The ultrathin sections were stained doubly by saturated uranyl acetate for $1 \mathrm{hr}$ and lead hydroxide for $30 \mathrm{~min}$. Such sampling was repeated daily until the 3rd day of the moth stage. Apart from the examination of the ultrastructure of the cell, the surface view of the cuticle covering the gland was examined electronmicroscopically by the chrome-carbon replica method, using cellulose acetobutylate film as the casting material. Light microscopy of the cell was also performed on paraffin sections fixed with CHAMPy's fluid and then subjected to post-osmication for 1 week.

\section{RESULTS}

\section{Fine Structure of the Surface of Cuticle Covering the Gland Cell}

Figs. 1 and 2 are respectively low and high magnifications of the chrome-carbon replica of the cuticular surface of a 1-day old female moth. As can be clearly seen in Fig. 1, the surface of the gland was divided by deep depressions into small hexagonal portions. This hexagon probably represents the border of each cell composing the gland. Numerous small processes, which were sometimes mammiform and sometimes hair-like, were present all over the surface (Fig. 1, P). Electron-microscopically discernible holes, however, were not seen on those processes.

\section{Ultrastructure of the Gland Cells}

Fig. 3 shows a sectional view of the above-described cuticular process on the surface of the gland. The process was composed of, like usual cuticle, three distinct layers (cuticulin, exocuticle and endocuticle according to the definition given by Locke, 1964). The outer two layers, cuticulin and exocuticle, had almost the same thickness to those of other parts of the cuticle. The endocuticle, however, was far thicker at the process. In the center of the process, a bundle of thin canals containing very electron-dense material was present (Fig. 3, Pc). It was recoginzed characteristically only in the process part, and seemed to be a modified form of the usual arboraceous pore canals found in the epidermal cuticle. Often a single canal or a few canals entered deeply into the exocuticle. Around such canals, thin endocuticular material branching from the bulk of the endocuticle was present. Although we could not define the actual point where the canal reaches the outermost cuticulin layer and opens, it is almost certain that the canal

Fig. 1 Chrome-carbon replica of the surface of the cuticle covering the alluring gland. Note the presence of numerous small processes.

Fig. 2 High magnification view of two processes at the cuticle.

Fig. 3 Sectional view of the cuticular process. Eleven-days old pupa. Note the presence of the dense bundle of pore canals in the center of the process.

G : cuticulin; En : endocuticle; Ex : exocuticle; P : process; Pc : pore canal. 


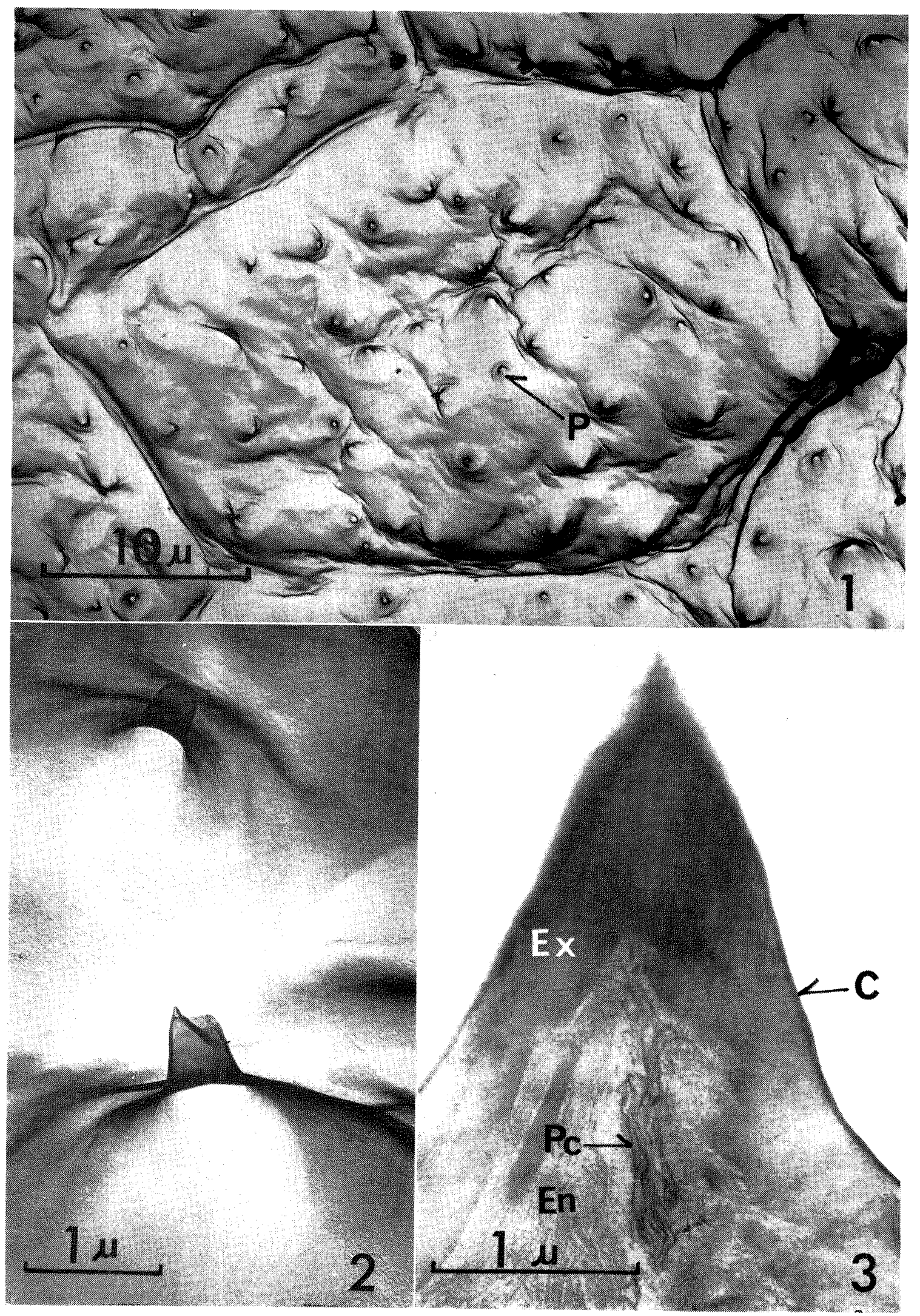


should do so. Thus it seems highly probable that this special kind of pore canal is the pathway for the transportation of the secretory substance of the alluring gland.

The fine structure of the gland cell lying under the cuticle at the 7 th day of pupal development is shown in Fig. 4. The nucleus was enveloped by a doublelayered nuclear membrane and contained numerous chromatin blobs and a few nucleoli. Well-developed Golgi apparatus, rough-surfaced endoplasmic reticulum and free ribosomes occupied almost the entire area of the cytoplasm. Though the Golgi apparatus was well-developed, there was no indication of marked secretory activity in it (Fig. 4, G). Thus the Golgi apparatus does not seem to be the site of the secretion of the alluring substance. Numerous mitochondria, with dense matrix and irregular array of cristae, were scattered throughout the cytoplasm. Short microvilli were present on the entire surface of the cuticular side. Thick basement membrane covered the haemocoel side of the cell, but it did not intrude into the intercellular space. The above-described features of the ultrastructure of the gland cell are almost similar to those in the usual epidermal cells other than the gland. A distinct difference between these two cell types lies in the presence of large globular structure containing some lipoidal material with medium electron density in the cytoplasm of the gland cell (Fig. 4, S). This globule cauld be seen clearly also in the light-microscopy of the CHampy-fixed cells. As Hayashi and Ito (1933) and Steinbreght (1964) have already claimed, this lipoidal material seems to represent the secretory substance of the gland cell containing bombykol in it.

Fig. 5 and its inset show a greatly magnified view of portion of the cytoplasm. In vicinity of the secretory globules, very often characteristic myelin figures were seen (Fig. 5, My). It was composed of numerous layers of electron-dense lipoid, and often contained one or several lipid droplets (inset, L) with medium electron density within it. Such lipid droplets with medium density are, most probably, a starting material of the secretory lipoid globules. Intermediate myelin figures containing from very small lipid droplets to large ones were observed here and there nearby the completed secretory globules. In addition to those myelin figures, there were numerous mitochondria with ordinary cristae and dense matrix and also partly myelinated mitochondria (Fig. 5, MM) losing their cristae. Here also the intermediate figures from usual mitochondria to mostly myelinated ones were observed. Thus we conclude that the secretory substance is originated from myelinated mitochondria and finally changes into lipoid globule.

The fine structure of the gland cell at the final day of pupal period, just before the emergence of the moth, is shown in Figs. 6 and 7 . Endoplasmic reticulum, both granular and agranular, was almost totally absent here. Instead, minute vesicles partially or wholly filled with dense substance (Fig. 6, V) were

Fig. 4 Fine structure of the gland cell, 7-days old pupa. Note the presence of large secretory globules.

Cu : cuticle; Er: endoplasmic reticulum; G : Golgi apparatus; $M$ : mitochondria,; Mv : microvilli; $\mathrm{N}$ : nucleus; $\mathrm{Nm}$ : nuclear membrane; $\mathrm{S}$ : secretory substance. 


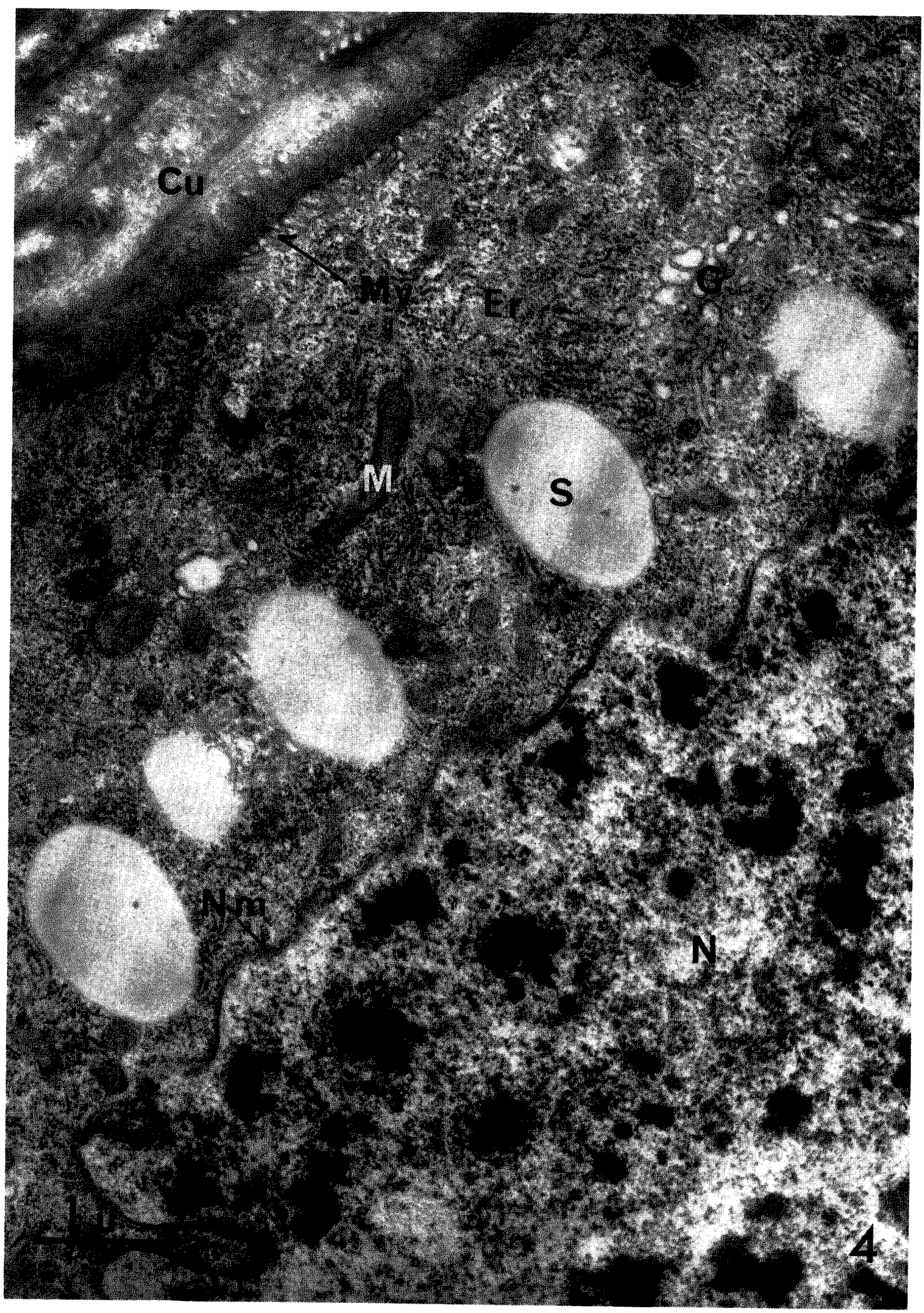


particularly evident in the peripheral cytoplasm close to the cuticle. These may represent the final stage of the secretory substance just before it is secreted from the cell surface. Microvilli were extensively developed and arrayed beautifully. Of particular interest was the characteristic and evident occurence of dense amorphous substance in and out of microvilli (arrows in Fig. 7). The state of this dense substance reveals the secreting figure through the plasma membrane of the microvilli. We consider that this is the case.

Though the ultrastructure of the cell in young moth did not show any marked difference from that in the pupa just before emergence, the older moth (Figs. 8 and 9) showed a remarkable change in its ultrastructure. The tip and side of extensively developed microvilli swelled up forming large vesicles (Fig. 8, SM). In such vesicles some irregular dense material, which may be incomplete myelin figures (Fig. 8, R), were distinctly observed. This probably represents remnants of decomposed and unsecreted lipoid substance. The cytoplasm in general also shows remarkable degenerating figure. Mitochondria swelled up enormously, losing their normal form and cristae (Fig. 9, M). Endoplasmic reticulum was almost broken. There was no Golgi apparatus.

Fig. 10 is a diagrammatical representation of the mechanism of production and secretion of the secretory substance as described in the previous sections.

\section{DISCUSSION}

Morphological investigations on the pheromone-producing glands of insects, both light- and electron-microscopic, have advanced extensively during recent years. They include, as their research objects, the glands secreting sex-attractants (in the bumble bee, Stein, 1962; in the silkworm, Steinbreaht, $1964 \mathrm{~b}$ ), trailfollowing pheromone (in the termite, STUART and SATIR, 1968) and aggregation pheromone (in the German cockroach, Ishi and Kuwahara, 1967). Most of these pheromones are in their nature some lipid-soluble substances, thus they appear morphologically as lipid droplets in the cell playing the role of carrier material. The workers, however, did not refer much to the mechanism of production and secretion of such lipid substance in the cell.

In his detailed electron-microscopic study of the alluring gland, Steinbrecht (1964 b) described the change of the ultrastructure during the late pupal and moth stages. His findings on the morphology of the gland generally corresponds to ours, except for some points which probably are due to the difference in techniques used. Though he discussed the morphology of the cell in detail, he referred only briefly to the production mechanism of the secretory substance by suggesting the possible role of the smooth-surfaced endoplasmic reticulum which he found in the late pupal stage in the production of secretory lipid substance. In our observations,

Fig. 5 High magnification of a portion of the cytoplasm, 7-days old pupa. Characteristic myelin figures with lipid droplet within them and half-myelinated mitochondria are present in the vicinity of secretory globules.

G : Golgi apparatus; L : lipid droplet; $\mathrm{M}$ : mitochondria; $\mathrm{MM}$ : myelinated mitochondria; $\mathrm{My}:$ myelin figure; $\mathrm{S}$ : secretory substance. 


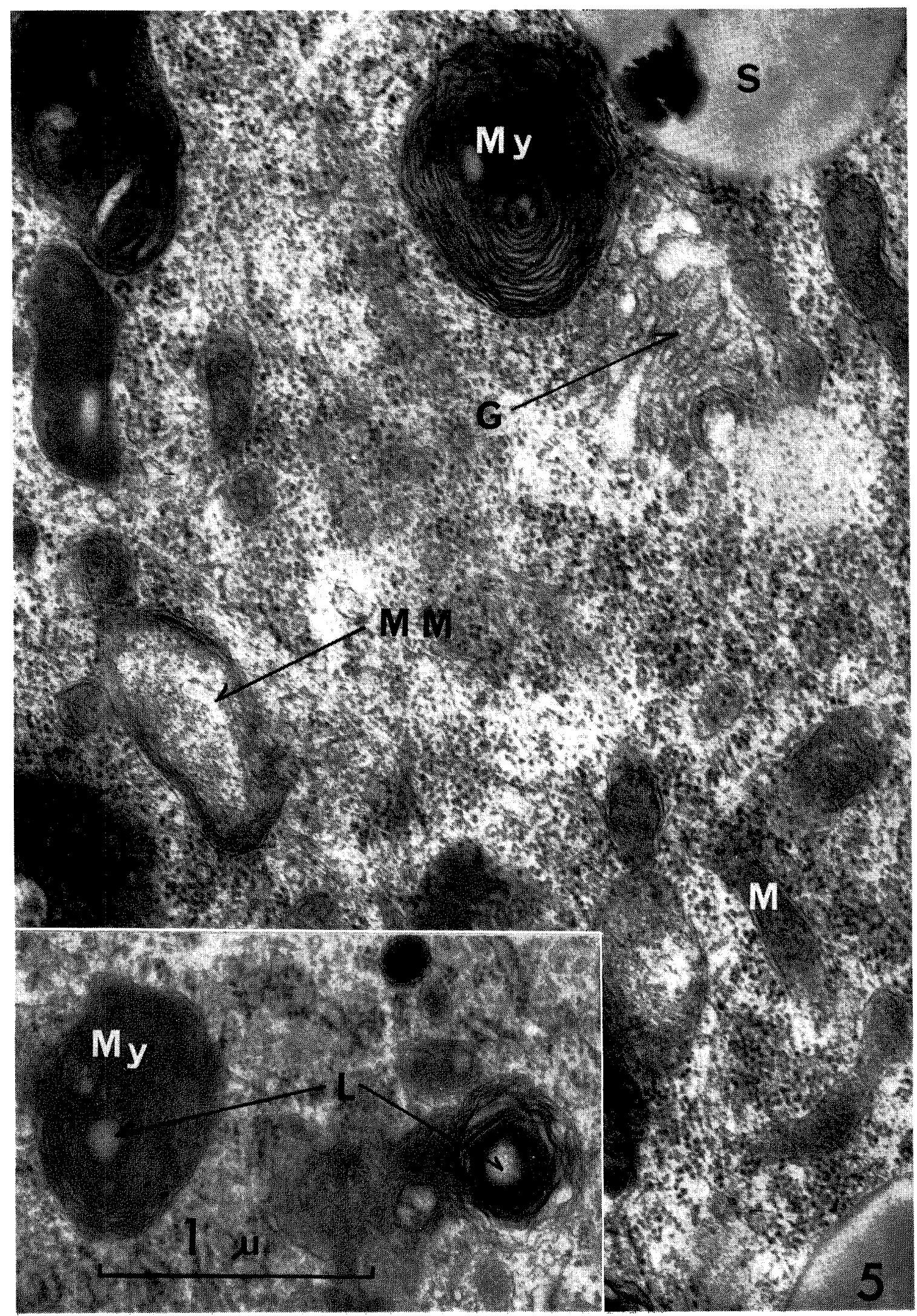


the endoplasmic reticulum in the cell actively producing the secretory substance was almost rough-surfaced (Fig. 4, Er), and it mostly disappeared in the cell secreting its product (Fig. 8). It is probable that the rough-surfaced endoplasmic reticulum would play some role in the production of proteinaceous material for replacement of the cuticle, like in the usual epidermal cells of the pupal integument.

Though the contribution of smooth-surfaced endoplasmic reticulum to the production of lipoidal substance is generally accepted since CHRisTensen and FAwCETT's work on the interstitial cell of the opossum testis (1961), it should be noted that this is never a general rule. Stein and Stein (1967 a, b, 1968) studied the pathway of lipid synthesis and secretion in several mammalian tissues using electron-microscopical radioautography. In lactating mammary gland cells the main site of lipid synthesis was the rough-surfaced endoplasmic reticulum, while in the liver cells it was both rough-surfaced and smooth ones. On the other hand, some evidences regarding the mitochondria as the origin of lipoidal substance have been accumulated during recent years. WARD (1962) claimed that the mitochondria in the amphibian yolk cells were the site of lipoid yolk formation. In the prothoracic glands of the silkworm and tussor silkworm, BEAURATON (1968) regarded a special kind of mitochondria as the initiating site of ecdysone synthesis, working together with the smooth endoplasmic reticulum. In our work, we found many intermediate figures between ordinary mitochondria and myelin figures (which Steinbrecht described as Einschliussen von komplexem Bau without further discussion) and also between myelin figures and secretory globules. On this basis, we regard the mitochondria as the starting organelle of secretory substance production, though the role of endoplasmic reticulum is still beyond discussion. Tакамото (1968) also reported the morphological change of the myelin figures into lipoid yolk in frog egg cells.

The transport of lipid through cell membrane, both the secretion from inside and uptake from outside of the cell, is generally difficult to be shown by morphological evidence, as is often discussed in the works concerning vertebrate intestine. The reason that we postulate the amorphous dense material at the tip or side of the microvilli (Figs. 6 and 7) as the actual figure of lipid secretion is as follows. First, this amorphous substance appears only at the stage in which the secreting activity is enhanced, such as final pupal stage or early moth stage. Both in the silkworm (Steinbrecht, $1964 \mathrm{a}$ ) and almond moth (Kuwahara et al., 1968) these stages are regarded as actively secreting stages. Second, the densities of the substance in the small vesicles at the peripheral cytoplasm (Fig. 6, V), that of the amorphous substance at microvilli, and that in the pore canal at the cuticular

Fig. 6 A portion of the cytoplasm and cuticle of the gland cell, 11-days old pupa just before emergence.

Fig. 7 High magnification of the portion of square in Fig. 6. Arrows indicate amorphous dense material at the surface of microvilli.

$\mathrm{Cb}$ : cell boundary; Cu : cuticle; D : desmosome; $\mathrm{M}$ : mitochondria; $\mathrm{Mv}$ : microvilli; $\mathrm{V}$ : vesicle with dense material. 

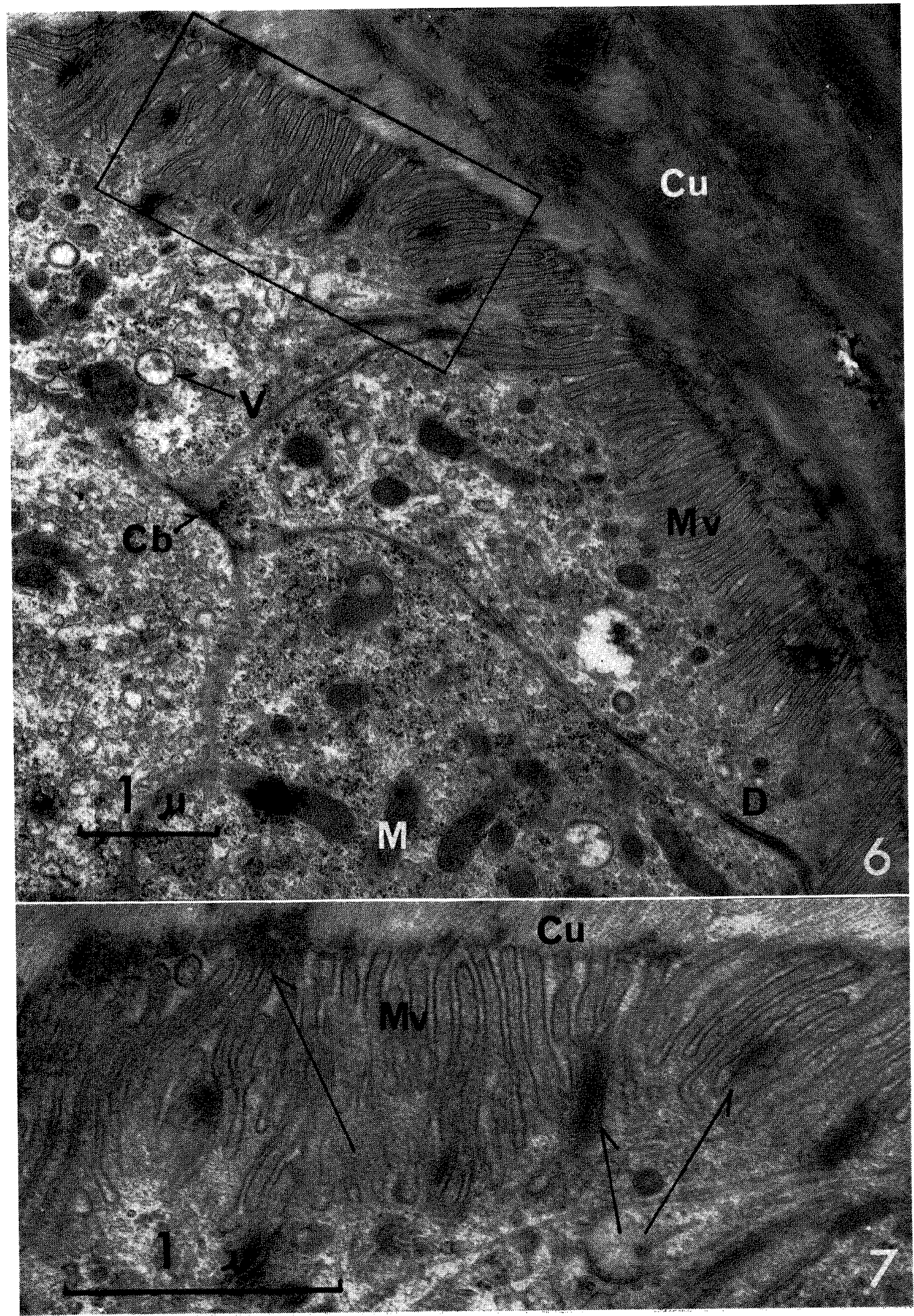


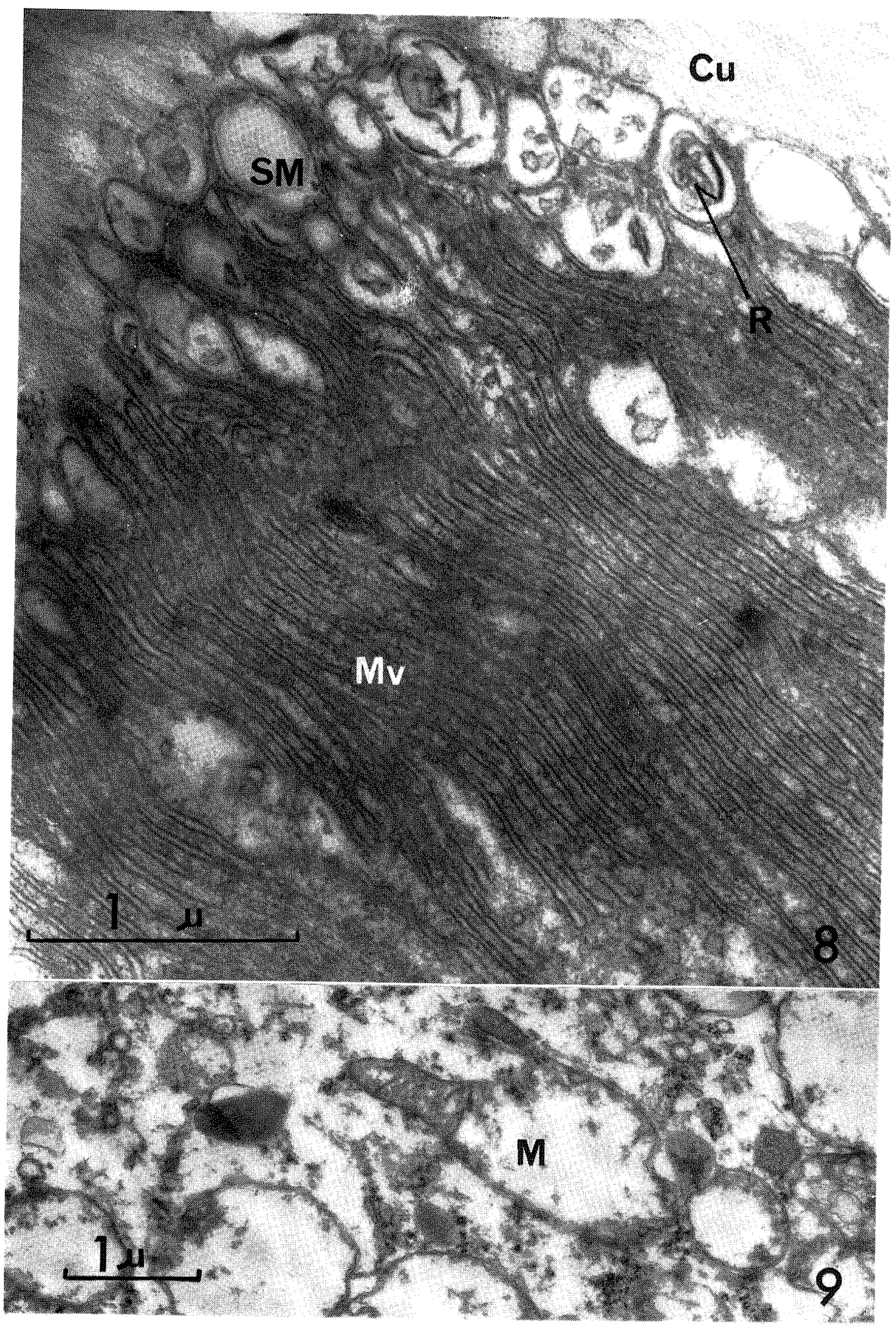




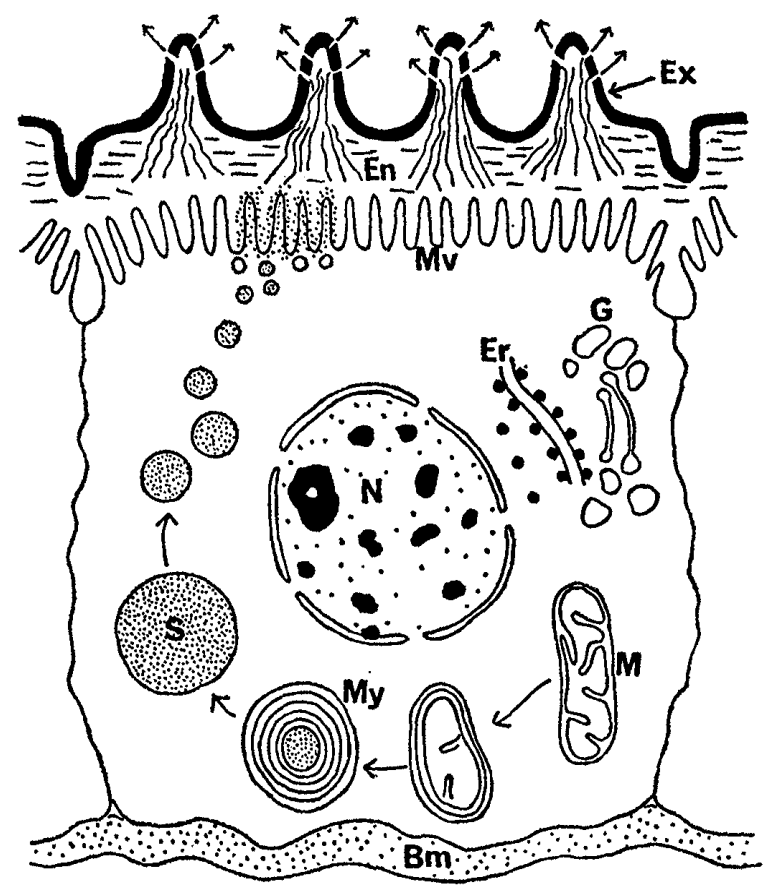

Fig. 10 Diagrammatical representation of the secretory activity in the alluring gland cell. $\mathrm{Bm}$ : basement membrane; En : endocuticle; Er : endoplasmic reticulum; Ex : exocuticle; $\mathrm{G}$ : Golgi apparatus; $\mathbf{M}$ : mitochondria; Mv : microvilli; $\mathrm{My}$ : myelin figure; $\mathrm{N}$ : nucleus; $\mathrm{S}$ : secretory substance.

process (Fig. 3, Pc) are almost equal with each other. Third, the substance in question does not resemble to any formerly known structure located at the plasma membrane, such as desmosome, hemidesmosome, septate desmosome, etc.

The degenerating figures of the cell ultrastructure (Figs. 8 and 9) in the older moth stage seems to be reasonable for the consideration of the dropped alluring activity in this stage. The degenerating mitochondria and endoplasmic reticulum in the older moth are reported also in the corpora allata of cecropia silkworm (WAKU and Gilbert, 1964).

The pore canal in the cuticular process of the gland seems to be a specially modified type for the purpose of the secretion of alluring substance. The presence of canals transporting lipoidal material such as cuticular wax are widely known among many insects (cf. Locke, 1964). The hexagonal surface view of the cuticle of the alluring gland somewhat resembles that of the wax-secreting gland in Calpodes reported by Locke (1964), though alluring gland does not have crater-

Fig. 8 Microvilli at the surface of the cell, 3-days old moth. Note the swollen tips of microvilli and remnant of secretory substance within them.

Fig. 9 A portion of cytoplasm, 3-days old moth. Mitochondria are enormously swollen.

$\mathrm{Cu}$ : cuticle; $\mathrm{M}$ : mitochondria; $\mathrm{Mv}$ : microvilli; $\mathrm{R}$ : remnant of secretory substance; SM : swollen tip of microvilli. 
shaped tubercles as in the wax gland and it has only mammiform or hair-like processes.

\section{REFERENCES}

Beauraton, J. A. (1968) Modifications ultrastructurales des cellules sécrétrices de la glande prothoracique de vers à soie au cours des deux derniers âges larvaires. I. Le chondriome, et ses relation avec le réticulum agranulaire. J. Cell Biol. $39: 501-525$.

Butenandt, A., R. Beckmann, D. Stamm and E. Hecker (1959) Über den Sexuallockstoff von Bombyx mori. Reindarstellung und Konstitution. Z. Naturforsch. 14 b : 283-284.

Christensen, A. K. and D. W. FAwcett (1961) The normal fine structure of opossum testicular interstitial cells. J. Biophys. Biochem. Cytol. $9: 653-670$.

Hayashi, T. and U. Iтo (1933) Histological observations of the alluring gland of the female silkmoth. J. Seric. Sci. 4:308-314. (in Japanese).

IshII, S. and Y. Kuwahara (1967) An aggregation pheromone of the German cockroach, Blattela germanica L. (Orthoptera : Blattelidae). I. Site of the pheromone production. Appl. Ent. Zool. $2: 203-217$.

Iто, H. (1915) On the alluring glands of the silkworm moths. Bull. Imp. Tokyo Seric. Col. 1:1-6.

Kuwahara, Y., G. Kitamura, F. Takahashi and H. Fukami (1968) Studies on sex pheromones of Pyralididae. I. Changes in the quantity of the sex pheromone in the female almond moth, Cadra cautella Walker (Phycitinae). Botyu-Kagaku 33 : 158-162.

Locke, M. (1964) The Physiology of Insecta. III. Ed. by M. Rockstein. Academic Press, New York and London. pp. 692.

Stein, G. (1962) UUber den Feinbau der Mandibeldrüse von Hummelmänchen. Z. Zellforsch. Mikroskop. Anat. 57 : 719.

Stein, O. and Y. STein (1967 a) Lipid synthesis, intracellular transport, storage, and secretion. I. Electron microscopic radioautographic study of liver after injection of tritiated palmitate or glycerol in fasted and ethanol-treated rats. J. Cell Biol. 33 : 319-340.

Stein, O. and Y. Stein (1967 b) ditto. II. Electron microscopic radioautographic study of the mouse lactating mammary gland. ibid. $34: 251-264$.

Stein, O. and Y. Stein (1968) ditto. III. Electron microscopic radioautographic study of the rat heart perfused with tritiated oleic acid. ibid. 36 : 63-78.

Strinbrechit, R. A. (1964 a) Die Abhängigkeit der Lockwirkung der Sexualduftorgans weiblicher Seidenspinner (Bombyx mori) von Alter und Kopulation. Z. vergl. Physiol. 48:341-356.

Steinbrechit, R. A. (1964 b) Feinstruktur und Histochemie der Sexualduftdrüse des Seidenspinners Bombyx mori L. Z. Zellforsch. Mikroskop. Anat. 64:227-261.

Stuart, M. and P. SATiR (1968) Morphological and functional aspects of an insect epidermal gland. J. Cell Biol. $36: 527-550$.

Takamoto, K. (1968) Studies on the process of amphibian oogenesis. VI. The formation of fatty yolk in Rana ornativentris. Zool. Mag. $77: 185-189$.

WAKU, Y. and L. I. GilBert (1964) The corpora allata of the silkmoth, Hyalophora cecropia: an ultrastructural study. J. Morph. $115: 69-96$.

WARD, R.T. (1962) The origin of protein and fatty yolk in Rana pipiens. II. Electron microscopical and cytochemical observations of young and mature oocytes. J. Cell Biol. 14 : 309-341. 